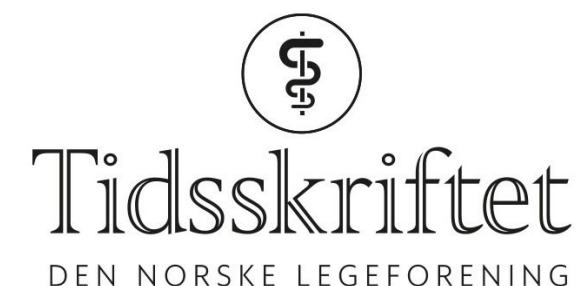

\title{
Nesens valvula - misforstått betegnelse på komplekst område
}

SPRÅKSPALTEN

\section{EIRIK MATHISEN}

Eirik Mathisen er spesialist i øre-nese-halssykdommer og overlege ved Øre-nese-halsavdelingen ved Sykehuset Østfold.

\section{MADS HENRIK STRAND MOXNESS}

E-post: mads.moxness@aleris.no

Mads Henrik Strand Moxness er spesialist i øre-nese-halssykdommer og overlege ved Aleris sykehus og medisinsk senter i Trondheim.

Innen nesekirurgi brukes de latinske uttrykkene valvula interna og valvula externa. Vi mener at dette er misvisende termer som ikke bør brukes.

Kirurger vektlegger i noen sammenhenger andre anatomiske forhold enn det som presenteres i anatomiundervisningen. Det kan være forskjell på teoretisk og klinisk anatomikunnskap, for eksempel ved klinisk nyttige forhold som plan mellom muskler, «sikre» områder å legge snitt eller områder mellom navngitte strukturer. Dette blir av enkelte omtalt som kirurgisk anatomi. Et eksempel fra nesekirurgien er uttrykkene valvula interna og valvula externa. I standard anatomibøker står det ingenting om disse begrepene.

Valvula kommer av det latinske ordet valva. Ifølge latinordboken betyr valva egentlig 'dørfløy', altså den ene halvdelen av en dobbeltdør. I medisinsk sammenheng blir valva vanligvis oversatt til klaff. En fysiologisk klaff er et organ som stopper eller regulerer strøm av væske eller luft. Ved å føye til diminutivsuffikset -ula uttrykker man at det dreier seg om en mindre utgave av substantivet.

\section{Neseklaff?}

The nasal valve ble første gang beskrevet i 1903 (1), men det er ingen konsensus om bruken av begrepet i rhinologisk litteratur. Man veksler også mellom bruk av ordene valva og valvula.

Valvula externa forstås av mange som et område avgrenset av neseseptum, mediale og laterale crura av alabrusken og premaksillen (figur 1). Betegnelsen brukes i litteraturen både om den todimensjonale neseboråpningen og den tredimensjonale vestibulum nasi. 


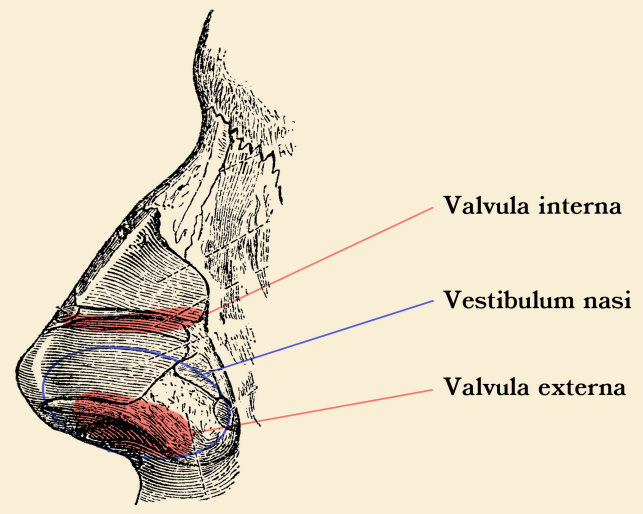

Figur 1 Den angivelige valvula interna og valvula externa. Illustrasjon: Nastasic/iStock, tilpasset av Tidsskriftet.

Valvula interna avgrenses vanligvis av neseseptum, nesegulvet, øvre lateralbrusk og fremre del av concha nasalis inferior (figur 1). Sistnevnte er det trangeste området i nesekaviteten, og et område som er aktuelt å modifisere kirurgisk ved nesetetthet.

Verken den eksterne eller interne valvula i nesen er som klaffer å regne, og i engelskspråklig litteratur har uttrykkene blitt foreslått erstattet med henholdsvis inlet area og nasal gateway (2).

\section{Uklare begreper}

Sannsynligvis er det fornuftig å beholde termen vestibulum nasi om det som på engelsk betegnes som external valve eller inlet area. Vi vil foreslå det norske uttrykket neseporten for internal valve eller nasal gateway.

Det viktigste spørsmålet er imidlertid om vi egentlig trenger disse begrepene i det hele tatt. Vi bør etterstrebe en terminologi som har et vitenskapelig fundament og som kan gi opphav til etterprøvbare resultater etter kirurgiske inngrep. Deskriptive tolkninger av endringer i external valve og internal valve etter eksempelvis rhinoplastikk har vist seg ikke å være etterprøvbare. Subjektive eller fysiske målemetoder som rhinomanometri eller akustisk rhinometri gir usikre resultater (3). Databaserte modeller med kunnskap om strømningsfysikk og aerodynamikk påviser effekt av endringer i fremre del av nesekaviteten (4) og kan representere en fremtidig objektiv målemetode etter nesekirurgi.

Internasjonal bruk av begreper endres neppe ved en artikkel i Tidsskriftets språkspalte, men uklar begrepsbruk gir dårlig kommunikasjon. Når man kommuniserer på norsk, bør man velge termer som mer treffende beskriver området man vil omtale. Etter vår mening er termene valvula externa og interna lite nyttige. Den etablerte anatomiske termen vestibulum nasi omfatter førstnevnte, mens neseporten kan være et mer treffende navn på sistnevnte.

\section{LITTERATUR:}

1. Mink PJ. Le nez comme voie respiratory. Presse Otolaryngol (Belg) 1903: 481-96.

2. Tripathi PB, Elghobashi S, Wong BJF. The myth of the internal nasal valve. JAMA Facial Plast Surg 2017; 19: 253-4. [PubMed][CrossRef]

3. Wexler DB, Davidson TM. The nasal valve: a review of the anatomy, imaging, and physiology. Am J Rhinol 2004; 18: 143-50. [PubMed][CrossRef]

4. Moxness MHS. The influence of the nasal airway in obstructive sleep apnea. Doktoravhandling. Trondheim: NTNU, 2018. 
Publisert: 6. mai 2019. Tidsskr Nor Legeforen. DOI: 10.4045/tidsskr.19.0012 (C) Tidsskrift for Den norske legeforening 2020. Lastet ned fra tidsskriftet.no 